\title{
EN DEFENS A DE LA EDUCACIÓN PÚBLICA, DEL DERECHO A LA EDUCACIÓN Y LA LEGALIDAD UNIVERSITARIA, DE ERIC PALMA
}

\author{
Jennifer Abate Cruces
}

Uno de los desafíos que plantea la Reforma Educacional prometida por el Gobierno de la Presidenta Michelle Bachelet es la revitalización de la educación pública en Chile junto con la eliminación efectiva del lucro, el copago y la selección. Los defensores del fortalecimiento del sistema estatal de educación suelen defender su relevancia, ya que es el responsable de la construcción de la República y de la democratización en el acceso a la enseñanza. Sin embargo, pocos son los que proponen, como Eric Palma, Profesor Titular de la Facultad de Derecho de la Universidad de Chile y Senador Universitario, que se trata de un derecho que deberíamos reclamar por la vía legal.

A través de lenguaje técnico, Palma asegura que desde sus inicios, a la Universidad de Chile le corresponde contribuir al desarrollo del patrimonio cultural y las identidades nacionales y el perfeccionamiento del sistema educacional del país. La Universidad, desde esta misión, debe propender al desarrollo nacional por medio de la investigación y la creación y postular al desarrollo integral, equilibrado y sostenible del país, aportando a la solución de sus problemas desde la perspectiva universitaria y promoviendo el bien común y la formación de una ciudadanía inspirada en valores democráticos, procurando el resguardo y enriquecimiento del acervo cultural nacional y universal.

Sin embargo, plantea el autor, si bien la Universidad ha intentado cumplir con esa misión desde sus orígenes, todo cambió en la década de 1980, cuando junto con una disminución drástica del aporte fiscal, se inició el desmembramiento de la Universidad. Desde ese momento, señala, y debido a que actualmente "el Estado no asume directamente el financiamiento de la mayor cobertura de la educación superior; hay presiones para eliminar la prohibición de lucrar; la ley del consumidor opera como único mecanismo de defensa ante la apertura irresponsable de carreras que no tienen campo laboral; empieza a concebirse al estudiante como mero cliente; y hay una conexión de las necesidades de las empresas con la actividad universitaria", entre otros agravantes, es necesario demandar al Estado de Chile por no permitirle a la Universidad de Chile cumplir con la misión que le fue encomendada. 
Lo anterior, a juicio de Palma, está plenamente establecido en el Pacto Internacional de Derechos Sociales, Económicos y Culturales suscrito por nuestro país y que obliga al Estado de Chile a proporcionar a las universidades estatales los recursos que permiten a su población satisfacer los derechos establecidos en dicho convenio.

Esa certeza fue la que llevó a Eric Palma, en 2011 y en su calidad de director de la Asociación de Académicos de la Facultad de Derecho de la Universidad de Chile (ACAUCH), a petición de un conjunto de organizaciones de profesores universitarios y de colegas, a hacer una presentación ante el relator de las Naciones Unidas para el derecho a la educación. En ella denunció la violación del Estado de Chile, en tanto que suscriptor del Pacto Internacional de Derechos Sociales, Económicos y Culturales, de sus obligaciones para con el derecho a la educación. Advirtió también sobre el peligro de la criminalización del movimiento social.

"En defensa de la educación pública, del derecho a la educación y la legalidad universitaria" contiene, además, la petición hecha ante el Mineduc para investigar el lucro en algunas universidades privadas que Palma y otros académicos identificaron expresamente, así como las gestiones realizadas ante la Contraloría General de la República y el Consejo Nacional de Educación a propósito del mismo tema. Incorpora también su intervención en la Comisión de la Cámara de Diputados que investigó la crisis de la Comisión Nacional de Acreditación.

\section{BIBLIOGRAFÍA}

Palma, Eric: "En defensa de la educación pública, del derecho a la educación y la legalidad universitaria". Santiago de Chile, Gráfica LOM (Impresores). Facultad de Derecho de la Universidad de Chile. 